\title{
受動関節機構を有する移動ロボットによる協調搬送制御* (ファジィ理論を利用した斜面路走行における搬送台の水平化制御)
}

\author{
浜口 雅史 ${ }^{* 1}$, 谷口 隆雄 ${ }^{* 1}$

\section{Cooperative Transfer Control by Using Mobile Robots with Passive Joint Mechanism (Level Control of Carrier Platform on Slope by Using Fuzzy Set Theory)}

\author{
Masafumi HAMAGUCHI ${ }^{* 1}$ and Takao TANIGUCHI \\ ${ }^{* 1}$ Interdisciplinary Graduate School of Science and Engineering, Shimane University \\ 1060 Nishikawatsu-cho, Matsue-shi, Shimane, 690-8504 Japan
}

This paper proposes a cooperative transfer control method by using three wheeled mobile robots (WMRs). One WMR is designated as a leader, and the other two WMRs are followers. A carrier platform is supported by links with passive joints on the WMRs. The carrier platform is always kept levelly when WMRs run along a straight path on a slope. The level control of the carrier platform is achieved by a position control of WMRs. The positions of the followers are controlled by using a fuzzy set theory to level the carrier platform, while the leader runs along the target path. Membership functions of the fuzzy set theory are designed by using a genetic algorithm. The usefulness of the proposed method is demonstrated through simulation and experimental results.

Key Words : Moving Robot, Intelligent Equipment, Automation, Fuzzy Set Theory, Genetic Algorithm, Cooperative Control, Level Control

\section{1. 緒言}

近年，移動機構を持たせたロボットの研究が盛んに行われている．これは，工場などの特殊な環境下だけにと どまらず，一般の家庭や病院，公共の施設など私たちの身近な領域にまで，ロボットの応用分野が拡大すること が予想されているからである. 一般的に， ロボットは物体を搬送する作業を行うことが多く，複数台の移動ロボ

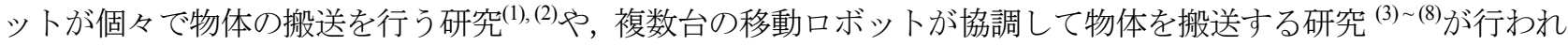
ている. また, 協調搬送機構の破損を防ぐため, コンプライアンス要素として受動関節を用いたものもある ${ }^{(9) \sim(11)}$. 筆者らは，受動関節を有する移動ロボットによる協調搬送制御を対象とし，移動ロボットの位置制御を行い，搬 送台を常に水平に保つ研究を行った ${ }^{(12)}$.これは，3 台の移動ロボットの相対位置を幾何学モデルより算出し, 搬 送台が水平となるように移動ロボットの相対位置を制御するものであった. しかし,「移動ロボットは, 同一平面 上にあるものとする」という条件が設定されており，その適用範囲が十分に広いとは言えないものであった。

本研究では, 文献(12)と同様に, 受動関節を有する移動ロボットによる協調搬送制御を対象とし, 移動ロボッ 卜の位置制御を行い，搬送台を常に水平に保つことを目的とするが，以下の条件を設定する.

（C1）移動ロボットは，低速で走行するものとする.

（C2）移動ロボットは，十分に滑らかな路面上を走行するものとする.

本研究では，大型の重量物の搬送を考えている．このような搬送物を高速で搬送したり，大きな起伏のある不整 地上で搬送したりすることは，極めて危険であり，非現実的である．よって，上記の条件を設定した．文献(12) では，「移動ロボットは，同一平面上にあるものとする」という厳しい条件であったが，これは幾何学モデルを利 用したためである. そこで, 幾何学モデルを使用せず，ファジィ理論を用いて搬送台を水平化する方法を提案す

\footnotetext{
* 原稿受付 2012 年 12 月 14 日

*1 正員, 島根大学大学院 総合理工学研究科（广690-8504 島根県松江市西川津町 1060）

E-mail: hamaguchi@ecs.shimane-u.ac.jp
} 
る. 本手法は, 文献(12)より適応範囲が広く, より実用的なものとなる. 移動ロボットの障害物回避や誘導（ナ ビゲーション) にファジィ理論を用いて良好な結果が得られている ${ }^{(13) \sim(16)}$. 本研究では, 搬送台を水平保持する ためにファジィ理論を利用する，具体的には，搬送台の姿勢と各リンクの第 4 関節角度ならびにリーダリンクの 第 1 関節角度の情報をもとにファジィ理論を用いて移動ロボットの相対位置を制御し，搬送台を水平に保持する 制御系を提案する.

本提案手法では，全ての関節角度ならびに全ての移動ロボットの位置・姿勢を計測する必要は無く，制御指令 值も簡単な代数計算で算出されるため, 文献(11)に比べて低コストな制御系を実現することができる. ファジィ 制御では, メンバーシップ関数によって制御性能が大きく変化するため, メンバーシップ関数の設計は非常に重

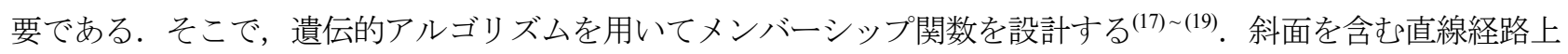
を走行させ，提案手法の有効性を確認する.

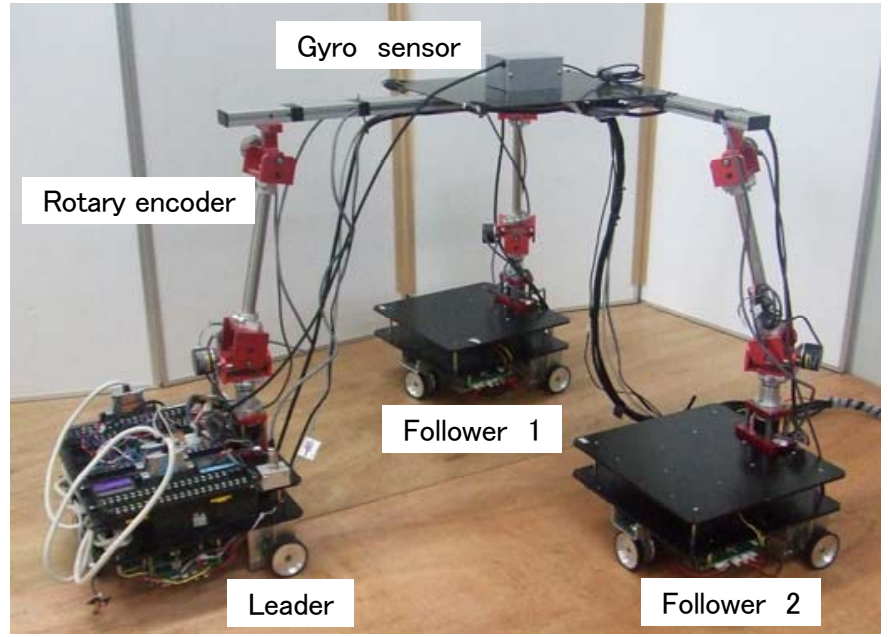

Fig. 1 Experimental equipment

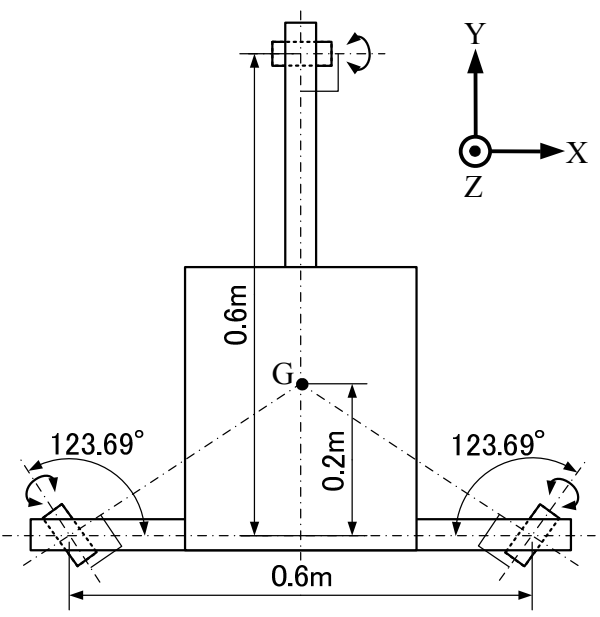

Fig. 2 Carrier platform (Top view)

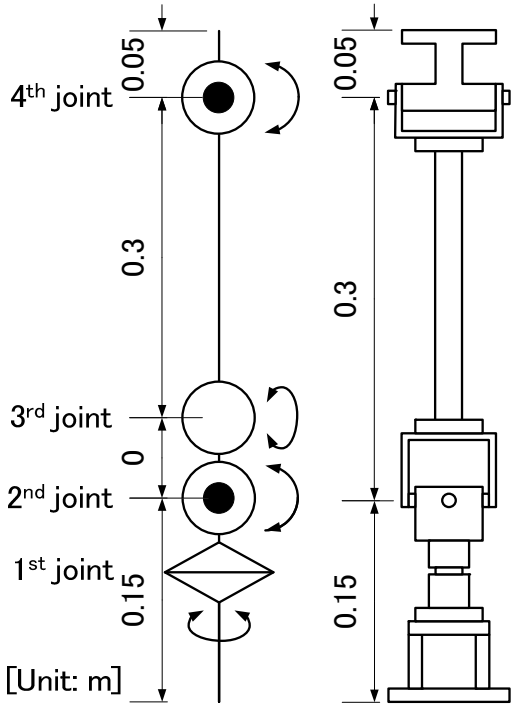

Fig. 3 Link with passive joints

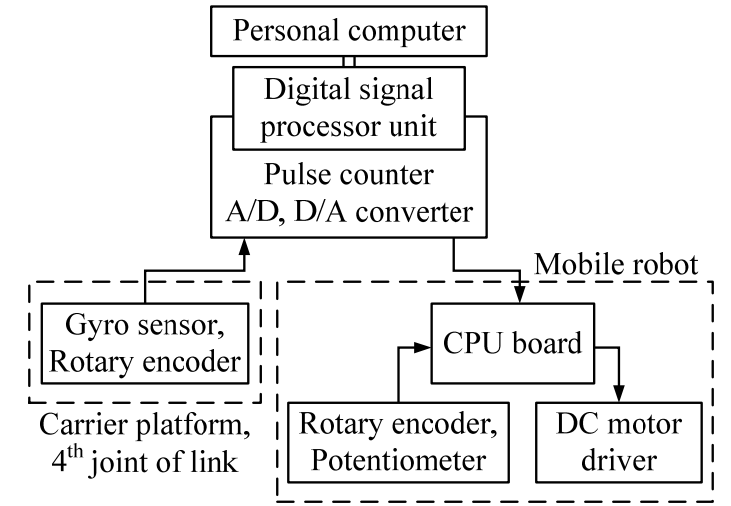

Fig. 4 Composition of experimental equipment

\section{2. 実験装置}

実験装置の外観を図 1 に示す. 移動ロボットは車輪型で, 動輪（DCモータ：4.6W）2 輪とステアリング輪（DC モータ：0.7W） 1 輪の 3 輪を持つ. 各移動ロボットの最大可搬質量は $10 \mathrm{~kg}$ であり，最大走行速度は $0.5 \mathrm{~m} / \mathrm{s}$ であ る. 動輪においてはロータリエンコーダ, ステアリング輪においてはポテンションメータによるフィードバック 
制御がなされる．移動ロボットの位置と姿勢は，左右の動輪のロータリエンコーダ值を用い，デッドレコニング （オドメトリ）により測定される. 進行方向に対し，前方のロボットをリーダ，右後方のものをフオロワ 1, 左 後方のものをフォロワ 2 と呼ぶものとする. 搬送台は 3 本のリンクによって支持され, 各リンクは移動ロボット に接続される. 図 2 に示すように，搬送台は T 字に組み合わせたアルミフレーム上に，搬送物を載せるためのス チール板を取り付けたものである．搬送台の傾きを計測するためのジャイロセンサ（アナログデバイス製 ADXRS610ABG）が搬送台上に取り付けられている．座標系 XYZ を水平路面上に設定し，X 軸周りの回転角を ピッチ角，Y 軸周りの回転角をロール角，Z 軸周りの回転角をヨー角と定義する．なお，回転角の正負は右ねじ の法則に従う。リンクの外形を図 3 に示寸。関節は全て受動関節であり, 同図のように移動ロボットの方から順 に番号付けされる. 第 4 関節は搬送台の重心方向に対して垂直な回転軸を持っている (図 2 参照). 第 2 関節と第 3 関節はユニバーサルジョイントとなっている．角度を計測する関節は，各リンクの第 4 関節ならびにリーダリ ンクの第 1 関節の計 4 個のみであり，ロータリエンコーダ（オムロン製 E6H-CWZ6C）を用いて計測する．ジャ イロセンサとロータリエンコーダの信号は，リーダに搭載された DSP ユニット（エムティティ製 s-BOX）に入力 される. DSP ユニットから各移動ロボットへ指令值が送信され, 移動ロボットの相対位置が制御される. そして, 搬送台が望みの姿勢に制御される. 各移動ロボットには CPU ボード (CPU:ルネサスエレクトロニクス製 SH7751) が搭載されており, 移動ロボットの位置制御は, このCPU ボードによって行われる. 実験装置の構成を図 4 に示 す．PC はDSP ユニットへのプログラム転送と計測データの取得時のみに使用する．シミュレーションならびに 実験用プログラムは，MathWorks 製の Matlab・Simulink を用いて構築した。 なお，制御周期は $1.0 \mathrm{kHz}$ とた.

\section{3. ファジィ理論を用いた協調搬送制御}

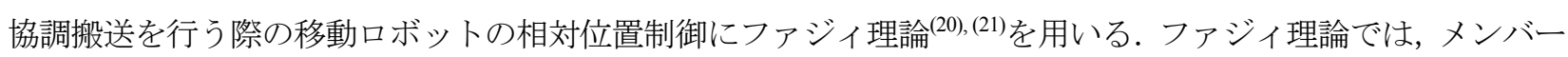
シップ関数を用い，ファジィ集合に属する度合い（グレード）を 0 ～1 の数值で表す. グレードが 1 に近ければそ の集合に属する度合いが大きく，0に近ければその集合に属する度合いが小さいことを意味する．ここでは，図 5 に示すメンバーシップ関数を用い, Min-Max 法による推論を行う.すなわち, 各ファジィルールの推論には AND 演算（Min）を用い，最終的な推論結果を求める際には OR 演算（Max）を用いる. 非ファジィ化には重心法を用 い, 推論結果を数值化する. 本研究では, 図 5 に示すように 7 つメンバーシップ関数を用いた. これは, メン バーシップ関数の個数（ファジィ推論の分割数）が多い方が, より制御性能が向上すると考えたためである.

搬送台を水平に保持するためのファジィルールを，実験装置の機構を考えて作成した．本研究では，予め与え た目標経路上をリーダに走行させ，搬送台が水平になるようにフォロワを移動させる．そのため，ファジィルー ルは，フォロワへの動作指令に関するものとなる．なお，実験装置の機構上，上り斜面と下り斜面では，フォロ ワの動作形態が異なる ${ }^{(12)}$ ．上り斜面ではリーダとフォロワ間の距離を変化させることにより，下り斜面ではフォ ロワリンクの第 4 関節が回転する方向へフォロワを移動させることにより，搬送台のピッチ角を制御する．その ため，ファジィルールを上り斜面と下り斜面で別に作成する必要がある. なお，水平路面上では，上り斜面での ファジィルールを用いて制御する.

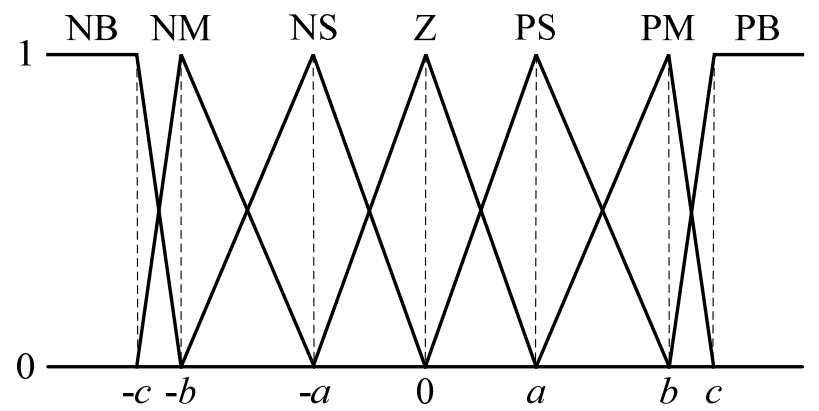

Fig. 5 Membership function of control method I

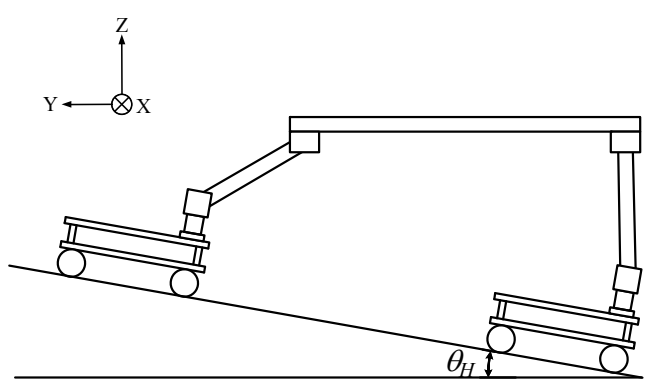

Fig. 6 Running robots on uphill 


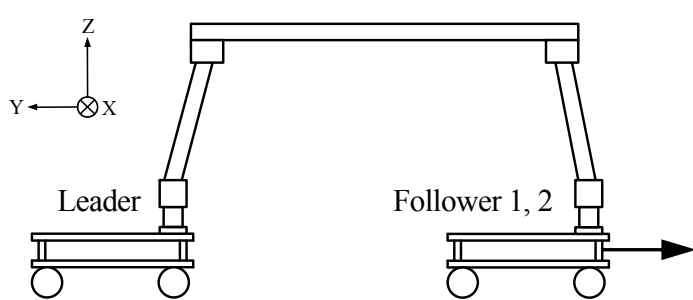

(a) Initial state (Side view)

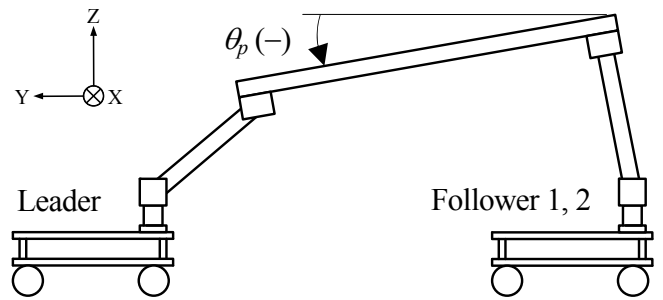

(b) Desired state on uphill (Side view)

Fig. 7 Action pattern for negative pitch angle of carrier platform

\section{$3 \cdot 1$ 上り斜面のファジィルール}

上り斜面路走行における搬送台の水平化制御のためのファジィルールについて以下に述べる.

\section{$3 \cdot 1 \cdot 1$ 搬送台のピッチ角制御}

上り斜面において，搬送台のピッチ角を零とするには，搬送台の前方を下げる必要がある (図 6 参照)。搬送台 の前方を下げるには，図７に示寸ようにフォロワの速度をリーダの速度より遅くし，リーダとフォロワ間距離を 長くすればよい. したがって, 搬送台のピッチ角 $\theta_{p}$, ピッチ角速度 $\omega_{p}$ を入力とし, フォロワの速度変化量 $\Delta v_{f}$ を出 力とするファジィルールを作成した．ピッチ角速度を入力に加えた理由は，PD 制御の D 制御に相当する効果を 期待したためである. 作成したルールを表 1 に示す. 表 1 では, 「 $\theta_{p}$ が負で大(NB)で， $\omega_{p}$ が負で大(NB)であれば,

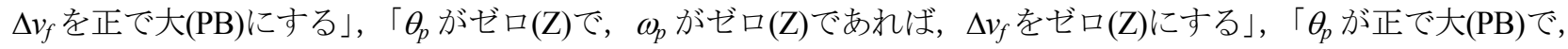
$\omega_{p}$ が正で大 $(\mathrm{PB})$ であれば, $\Delta v_{f}$ を負で大 $(\mathrm{NB})$ にする」等のルールになっている. 表中のラベルは, NB: Negative Big, NM: Negative Medium, NS: Negative Small，Z: Zero，PS: Positive Small，PM: Positive Medium, PB: Positive Big を意 味し, これらのメンバーシップ関数は図 5 のように与えられる. メンバーシップ関数の設計法については, 後述 する.

Table 1 Fuzzy rule of $\Delta v_{f}$ for pitch angle control on uphill

\begin{tabular}{|c|c|c|c|c|c|c|c|}
\hline$\omega_{p} \theta_{p}$ & NB & NM & NS & $Z$ & PS & PM & PB \\
\hline NB & PB & PB & PM & PM & PS & PS & Z \\
\hline NM & PB & PM & PM & PS & PS & Z & NS \\
\hline NS & PM & PM & PS & PS & Z & NS & NS \\
\hline Z & PM & PS & PS & Z & NS & NS & NM \\
\hline PS & PS & PS & Z & NS & NS & NM & NM \\
\hline PM & PS & Z & NS & NS & NM & NM & NB \\
\hline PB & Z & NS & NS & NM & NM & NB & NB \\
\hline
\end{tabular}

\section{$3 \cdot 1 \cdot 2$ 搬送台のロール角制御}

フォロワリンクの第 4 関節角度を初期值に保つことにより，搬送台のロール角 $\theta_{r}$ を零にする. これにより，水 平路面上を走行した際には，搬送台の高さを初期值とすることができ，搬送台の上下動を防ぐこともできる．フ オロワリンクの第 4 関節の角度 $\theta_{f 4}$ と角速度 $\omega_{54}$ を入力とし, フォロワの速度変化量 $\Delta v_{f}$ と舵角変化量 $\Delta \phi_{f}$ を出力とす るファジィルールを作成した．なお，フォロワリンクの第 4 関節角度は，フォロワが外側に広がる方向を正（図 8 (a)参照) とした. 作成したルールを表 2 に示寸. 表中の上段が速度変化量, 下段が舵角変化量を表し, 下段に はフォロワ 1 とフォロワ 2(括弧内）を併せて示した. 舵角変化量のラベルは, 1 文字目が方向を示す R: Right, L: Left を， 2 文字目が大きさ B: Big，M: Medium，S: Small を表す．例えば，「 $\theta_{j 4}$ が負で大（NB）で， $\omega_{f 4}$ が負で

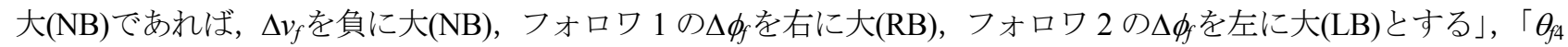
がゼロ(Z)で， $\omega_{f 4}$ がゼロ(Z)であれば， $\Delta v_{f}$ をゼロ(Z)，フォロワ 1 と 2 の $\Delta \phi_{f}$ ゼロ(Z)にする」，「 $\theta_{f 4}$ が正で大(PB),

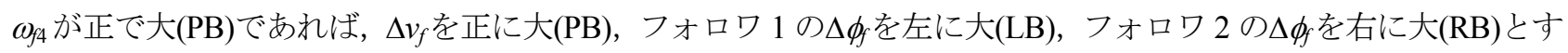


る」を意味する，速度変化量については，フォロワ 1 と 2 は同じルールになり，舵角変化量については，右(R) と左 $(\mathrm{L})$ が入れ替わったものになる，舵角変化量に関するメンバーシップ関数も図 5 のように与えるが， N $\rightarrow \mathrm{L}, \mathrm{P}$ $\rightarrow \mathrm{R}$ に変更したものになる.

\section{$3 \cdot 1 \cdot 3$ 搬送台のヨー角制御}

リーダ・フォロワ型協調搬送では，リーダの後をフォロワが追従して走行する．すなわち，リーダ，フォロワ そして搬送台のヨー角が同一となるように走行する．リーダと搬送台のヨー角が同一であれば，リーダリンクの 第 1 関節角度は初期值の零となる. よって, リーダリンクの第 1 関節角度を零に保ち続けるように制御する. リ 一ダリンクの第 1 関節の角度 $\theta_{l 1}$ と角速度 $\omega_{l 1}$ を入力とし, フォロワの舵角変化量 $\Delta \phi_{f}$ を出力とするファジィルール を作成した. 作成したルールを表 3 に示す.なお, リーダが搬送台に対して右を向いているときの $\theta_{11}$ を正とする.

Table 2 Fuzzy rule of $\Delta v_{f}$ and $\Delta \phi_{f}$ for roll angle control on uphill

\begin{tabular}{|c|c|c|c|c|c|c|c|}
\hline$\omega_{f 4} \quad \theta_{f 4}$ & NB & NM & NS & Z & PS & PM & PB \\
\hline \multirow{2}{*}{ NB } & NB & NB & NM & NM & NS & NS & Z \\
\hline & RB (LB) & RB (LB) & RM (LM) & RM (LM) & RS (LS) & RS (LS) & $\mathrm{Z}(\mathrm{Z})$ \\
\hline \multirow{2}{*}{ NM } & NB & NM & NM & NS & NS & $\mathrm{Z}$ & PS \\
\hline & RB (LB) & RM (LM) & RM (LM) & RS (LS) & RS (LS) & $Z(Z)$ & LS (RS) \\
\hline \multirow{2}{*}{ NS } & NM & NM & NS & NS & Z & PS & PS \\
\hline & RM (LM) & RM (LM) & RS (LS) & RS (LS) & $\mathrm{Z}(\mathrm{Z})$ & LS (RS) & LS (RS) \\
\hline \multirow{2}{*}{ Z } & NM & NS & NS & $\mathrm{Z}$ & PS & PS & PM \\
\hline & RM (LM) & RS (LS) & RS (LS) & $Z(Z)$ & LS (RS) & LS (RS) & LM (RM) \\
\hline \multirow{2}{*}{ PS } & NS & NS & Z & PS & PS & PM & PM \\
\hline & RS (LS) & RS (LS) & $Z(Z)$ & LS (RS) & LS (RS) & LM (RM) & LM (RM) \\
\hline \multirow{2}{*}{ PM } & NS & $\mathrm{Z}$ & PS & PS & PM & PM & PB \\
\hline & RS (LS) & $Z(Z)$ & LS (RS) & LS (RS) & LM (RM) & LM (RM) & $\mathrm{LB}(\mathrm{RB})$ \\
\hline \multirow{2}{*}{ PB } & $\mathrm{Z}$ & PS & PS & PM & PM & PB & PB \\
\hline & $Z(Z)$ & LS (RS) & LS (RS) & LM (RM) & LM (RM) & LB (RB) & $\mathrm{LB}(\mathrm{RB})$ \\
\hline
\end{tabular}

$※$ Upper : $\Delta v_{f}$, Lower : $\Delta \phi_{f}$, ( ) : Follower 2

Table 3 Fuzzy rule of $\Delta \phi_{f}$ for yaw angle control on uphill and downhill

\begin{tabular}{|c|c|c|c|c|c|c|c|}
\hline$\omega_{\omega_{l 1}} \theta_{l 1}$ & NB & NM & NS & Z & PS & PM & PB \\
\hline NB & LB & LB & LM & LM & LS & LS & Z \\
\hline NM & LB & LM & LM & LS & LS & Z & $\mathrm{RS}$ \\
\hline NS & LM & LM & LS & LS & Z & $\mathrm{RS}$ & $\mathrm{RS}$ \\
\hline Z & LM & LS & LS & Z & $\mathrm{RS}$ & $\mathrm{RS}$ & $\mathrm{RM}$ \\
\hline PS & LS & LS & Z & $\mathrm{RS}$ & $\mathrm{RS}$ & $\mathrm{RM}$ & $\mathrm{RM}$ \\
\hline PM & LS & Z & $\mathrm{RS}$ & $\mathrm{RS}$ & $\mathrm{RM}$ & $\mathrm{RM}$ & $\mathrm{RB}$ \\
\hline PB & Z & $\mathrm{RS}$ & $\mathrm{RS}$ & $\mathrm{RM}$ & $\mathrm{RM}$ & $\mathrm{RB}$ & $\mathrm{RB}$ \\
\hline
\end{tabular}

\section{$3 \cdot 1 \cdot 4$ 最終的なフォロワの速度と舵角の算出方法}

各フォロワの最終的な速度変化量 $\Delta v_{f}$ と舵角変化量 $\Delta \phi_{f}$ は次式で算出される. 


$$
\Delta v_{f}=\Delta v_{f}^{p}+\Delta v_{f}^{r}, \quad \Delta \phi_{f}=\Delta \phi_{f}^{r}+\Delta \phi_{f}^{y}
$$

ここで， $\Delta v_{f}^{p}$ と $\Delta v_{f}^{r}$ はそれぞれ，ピッチ角制御とロール角制御の制御則から算出された速度変化量を表し， $\Delta \phi_{f}^{r}$ と $\Delta \phi_{f}^{y}$ はそれぞれ， ロール角制御とヨー角制御の制御則から算出された舵角変化量を表す. 現在のフォロワの速度 ならびに舵角に，これらの変化量が加えられる．なお，フォロワには，リーダと同じ速度パターンが予め与えら れており，速度変化量 $\Delta v_{f}$ が常に零であれば，フォロワはリーダと全く同じ速度で走行することになる.

\section{$3 \cdot 2$ 下り斜面のファジィルール}

下り斜面路走行における搬送台の水平化制御のためのファジィルールについて以下に述べる.

\section{$3 \cdot 2 \cdot 1$ 搬送台のピッチ角制御}

下り斜面において，搬送台のピッチ角を零とするには，搬送台の後方を下げる必要がある．本装置の機構上， リーダとフォロワ間距離を変化させても，搬送台の後方を大きく下げることができない．そこで，図 8 に示すよ うに，フォロワリンクの第 4 関節が回転する方向へフォロワを移動させ，搬送台の後方を下げることにした．搬 送台のピッチ角 $\theta_{p}$, ピッチ角速度 $\omega_{p}$ を入力とし, フォロワの舵角変化量 $\Delta \phi_{f}$ を出力とするファジィルールを作成し た. 作成したルールを表 4 に示す. 括弧内に示したフォロワ 2 の舵角変化量は, フォロワ 1 のそれの右 $(\mathrm{R})$ と左 $(\mathrm{L})$ が入れ替わったものになる。

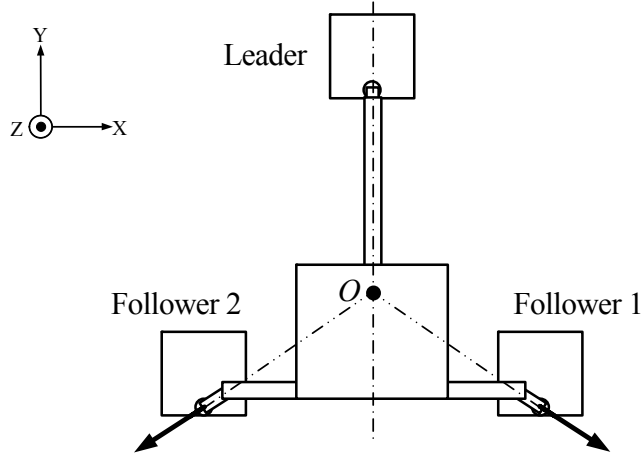

(a) Initial state (Top view)

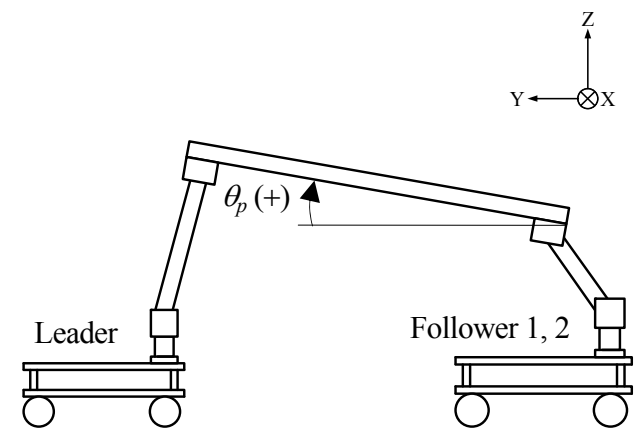

(b) Desired state on downhill (Side view)

Fig. 8 Action pattern for positive pitch angle of carrier platform

Table 4 Fuzzy rule of $\Delta \phi_{f}$ for pitch angle control on downhill

\begin{tabular}{|c|c|c|c|c|c|c|c|}
\hline$\omega_{p} \theta_{p}$ & NB & NM & NS & Z & PS & PM & PB \\
\hline NB & $\mathrm{RB}$ (LB) & $\mathrm{RB}$ (LB) & $\mathrm{RM}(\mathrm{LM})$ & $\mathrm{RM}(\mathrm{LM})$ & RS (LS) & RS (LS) & $Z(Z)$ \\
\hline NM & $\mathrm{RB}(\mathrm{LB})$ & $\mathrm{RM}(\mathrm{LM})$ & $\mathrm{RM}(\mathrm{LM})$ & RS (LS) & RS (LS) & $Z(Z)$ & LS (RS) \\
\hline NS & $\mathrm{RM}(\mathrm{LM})$ & RM (LM) & RS (LS) & RS (LS) & $\mathrm{Z}(\mathrm{Z})$ & LS (RS) & LS (RS) \\
\hline Z & $\mathrm{RM}(\mathrm{LM})$ & RS (LS) & RS (LS) & $Z(Z)$ & LS (RS) & LS (RS) & $\mathrm{LM}(\mathrm{RM})$ \\
\hline PS & RS (LS) & RS (LS) & $Z(Z)$ & LS (RS) & LS (RS) & LM (RM) & LM (RM) \\
\hline PM & RS (LS) & $Z(Z)$ & LS (RS) & LS (RS) & $\mathrm{LM}(\mathrm{RM})$ & LM (RM) & LB (RB) \\
\hline PB & $Z(Z)$ & LS (RS) & LS (RS) & LM (RM) & LM (RM) & LB (RB) & LB (RB) \\
\hline
\end{tabular}

$※(\quad)$ : Follower 2 
Table 5 Fuzzy rule of $\Delta \phi_{f}$ for roll angle control on downhill

\begin{tabular}{|c|c|c|c|c|c|c|c|}
\hline$\Delta \omega_{4} \Delta \theta_{4}$ & NB & NM & NS & Z & PS & PM & PB \\
\hline NB & RB (LB) & RB (LB) & RM (LM) & RM (LM) & RS (LS) & RS (LS) & Z (Z) \\
\hline NM & RB (LB) & RM (LM) & RM (LM) & RS (LS) & RS (LS) & Z (Z) & LS (RS) \\
\hline NS & RM (LM) & RM (LM) & RS (LS) & RS (LS) & Z (Z) & LS (RS) & LS (RS) \\
\hline Z & RM (LM) & RS (LS) & RS (LS) & Z (Z) & LS (RS) & LS (RS) & LM (RM) \\
\hline PS & RS (LS) & RS (LS) & Z (Z) & LS (RS) & LS (RS) & LM (RM) & LM (RM) \\
\hline PM & RS (LS) & Z (Z) & LS (RS) & LS (RS) & LM (RM) & LM (RM) & LB (RB) \\
\hline PB & Z (Z) & LS (RS) & LS (RS) & LM (RM) & LM (RM) & LB (RB) & LB (RB) \\
\hline
\end{tabular}

$※(\quad)$ : Follower 2

\section{$3 \cdot 2 \cdot 2$ 搬送台のロール角制御}

フォロワリンクの第 4 関節角度差 $\Delta \theta_{4}$ と, 角速度差 $\Delta \omega_{4}$ を入力とし, フォロワの舵角変化量 $\Delta \phi_{f}$ を出力とするフ アジィルールを作成した．なお， $\Delta \theta_{4}$ と $\Delta \omega_{4}$ は，次式で算出される.

$$
\Delta \theta_{4}=\theta_{f 1,4}-\theta_{f 2,4}, \quad \Delta \omega_{4}=\omega_{f 1,4}-\omega_{f 2,4}
$$

ここで, $\theta_{f 1,4}$ と $\theta_{f, 4}$ はそれぞれ，フォロワ 1 とフォロワ 2 のリンクの第 4 関節角度であり， $\omega_{f 1,4}$ と $\omega_{12,4}$ はそれぞれ， フォロワ 1 とフォロワ 2 のリンクの第 4 関節角速度である. フォロワリンクの第 4 関節角度差を零とすることで, 搬送台のロール角を零にする. 作成したルールを表 5 に示寸．括弧内に示したフォロワ 2 の舵角変化量は，フォ ロワ 1 のそれの右 $(\mathrm{R})$ と左 $(\mathrm{L})$ が入れ替わったものになる.

\section{$3 \cdot 2 \cdot 3$ 搬送台のヨ一角制御}

搬送台のヨー角制御は，上り斜面と同じ制御方法となるため，上り斜面と同じルール（表 3）ならびにメンバ ーシップ関数を用いる.

\section{$3 \cdot 2 \cdot 4$ 最終的なフォロワの舵角と走行速度の算出方法}

各フォロワの最終的な舵角変化量 $\Delta \phi$ 快次式で算出される.

$$
\Delta \phi_{f}=\Delta \phi_{f}^{p}+\Delta \phi_{f}^{r}+\Delta \phi_{f}^{y}
$$

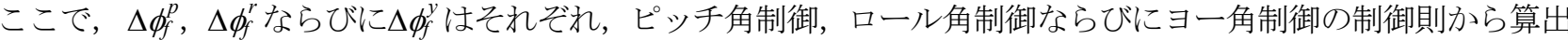
された舵角変化量である．現在のフォロワの舵角に，この変化量が加えられる.

図 9 は，フォロワ 1 の速度 $v_{f 1}$ の算出方法を図示したものであり，点 $\mathrm{G}$ は搬送台中心（図 2 参照）を示してい る. なお，フォロワの舵角䄈はフォロワが外側に開く方向を正とする．下り斜面では，フォロワリンクの第 4 関 節が回転する方向へフォロワを移動させる必要がある．したがって， $v_{f 1}$ を次式により与える．なお， $v_{l}$ はリーダ の走行速度を， $\Phi_{s}$ はフォロワリンクの第 4 関節の取り付け角度を表し，本装置では $\Phi_{s}=56.31[\mathrm{deg}]$ である.

$$
v_{f 1}=\frac{v_{l} \sin \left(\Phi_{s}\right)}{\sin \left(180-\Phi_{s}-\phi_{f 1}\right)}
$$

ここでは，舵角操作によるフォロワの向き（方位角）の変化量は小さく，フォロワとリーダの方位角の差は微小 となるため，フォロワとリーダの方位角は同一であるものとして考えた．フォロワ 2 も同様に考えて，走行速度 福を算出する. 

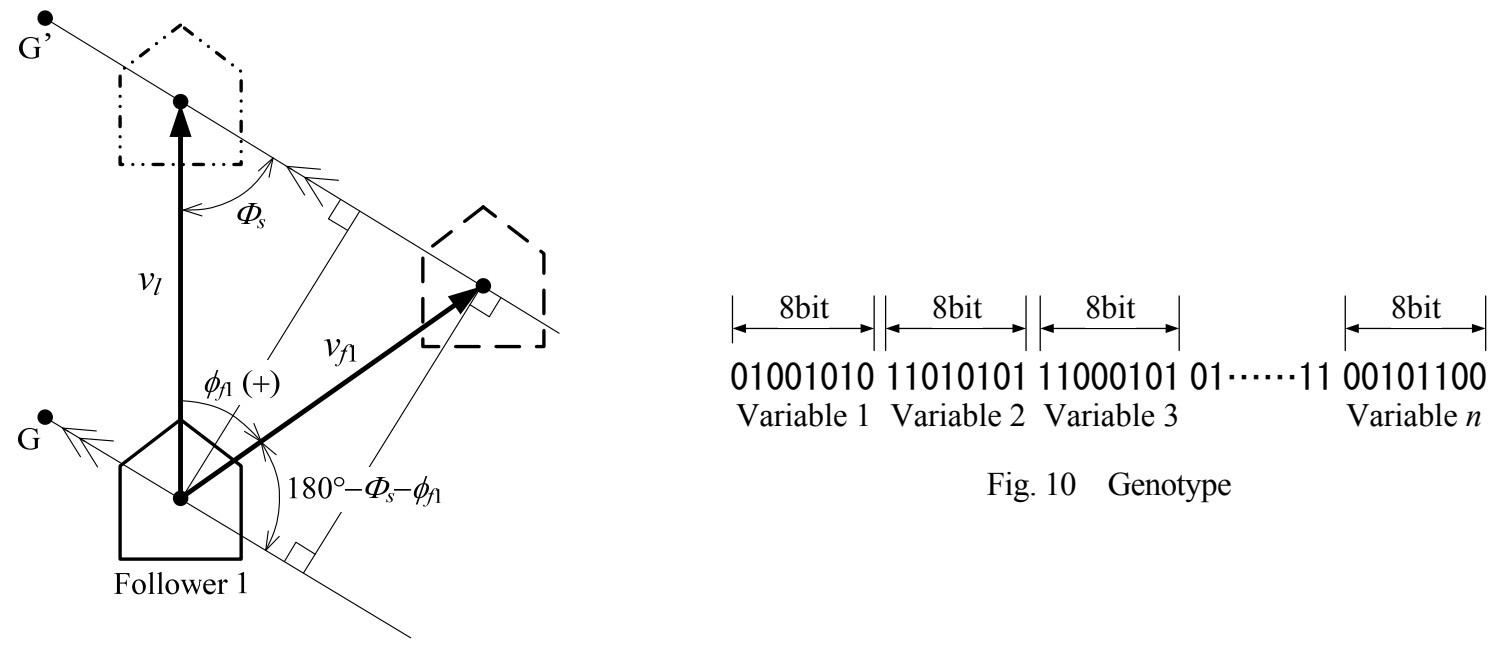

Fig. 10 Genotype

Fig. 9 Velocity of Follower 1 on downhill

\section{$3 \cdot 3$ メンバーシップ関数の設計法}

遺伝的アルゴリズム（GA）(22),(23)を用いたメンバーシップ関数の設計法を以下に述べる.

\section{$3 \cdot 3 \cdot 1 \quad$ 設計変数のコード化，デコード化ならびに遺伝子型}

本研究では, 図 5 に示した形状のメンバーシップ関数を用いるため, その頂点位置を決定することにより, メ ンバーシップ関数の形状を設計する. 頂点の数は 7 つあるが，簡略化のため， Z の頂点は 0 に固定し， 0 を中心 に左右対称なメンバーシップ関数を用いることにする. よって，1つのファジィ集合について，頂点位置 $a, b, c$ の 3 つが設計変数となる. 例えば，上り斜面のピッチ角制御では，ファジィルールの前件部の $\theta_{p}$ と $\omega_{p}$, ならびに 後件部の $\Delta v_{f}$ の計 3 つのファジィ集合があるため, 設計変数の個数 $n$ は, $n=3 \times 3=9$ となる. ここでは, 設計変 数の值を 2 進数で表現するバイナリコーディングを用い, 1 変数の bit 数を $8 \mathrm{bit}$ とした. したがって, 各ファジィ ルールにおける遺伝子型は図 10 のようになる. 上り斜面のピッチ角制御では，初めの 3 個の変数が前件部の $\theta_{p}$ に関する頂点位置を, つぎの 3 個の変数が前件部の $\omega_{p}$ に関する頂点位置を, 最後の 3 個の変数が後件部の $\Delta v_{f} に$ 関する頂点位置を表す．8bit の各変数 num は式(5)を用いてデコード化され，実数值 val が得られる.

$$
v a l=\frac{v a l_{\max }}{2^{8}} \times(n u m+1)
$$

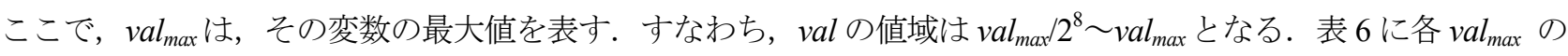
值を示寸が，これらの值は実験条件や予備実験から決定した. 各組の 3 個の変数を式(5)により実数化した後，そ の大小関係をもとに，小さいものから順に $a, b, c$ の值とする.

\section{$3 \cdot 3 \cdot 2$ 適合度}

GA は，ある環境に適した個体ほど生存し，その個体の子孫が増えてゆくという，自然界の生物の進化過程を 模倣したアルゴリズムである. 環境にどの程度適しているかを適合度で数值化する. すなわち, 個体の遺伝子型 を変数とした適合度の最大值問題と考えることができる，本研究では，次式の適合度 $f$ 用いた.

$$
f=\frac{1}{J+p}, \quad J=\frac{1}{t_{f}} \int_{0}^{t_{f}}|\alpha| d t
$$

ここで， $t_{f}$ はシミュレーション終了時間， $p$ はペナルティ項， $\alpha$ は評価角度を表す. 制約条件として, ロボットの 最大加速度ならびにリンク関節の可動範囲を与え, これらの制約条件を満たさなかったときに, $p=10$ のペナル ティが課される，これにより，fの值は低くなり，その個体が淘汰される確率は高くなる， $\alpha$ に，各制御則にお いて評価される角度が入る. 寸なわち, 搬送台のピッチ角制御では, 搬送台のピッチ角 $\theta_{p}$ が，ロール角制御では, 
搬送台のロール角 $\theta_{r}$ が，ヨー角制御では，リーダリンクの第 1 関節の角度 $\theta_{l 1}$ が $\alpha$ に入る. 搬送中に，これらの角 度の絶対值が小さいものほど， $f$ の值は高くなる. 各個体の遺伝子型に基づくメンバーシップ関数を用いた協調 搬送制御シミュレーションを行い，そのシミュレーション結果から $f$ の值を算出する.

Table 6 Values of $v_{\max }$

\begin{tabular}{|c|c|c|c|c|}
\hline \multicolumn{4}{|c|}{ Rule } & $v a l_{\max }$ \\
\hline \multirow{10}{*}{ Uphill } & \multirow{3}{*}{ Pitch } & \multirow{2}{*}{ Antecedent } & $\theta_{p}[\mathrm{deg}]$ & 5.0 \\
\hline & & & $\omega_{p}[\mathrm{deg} / \mathrm{s}]$ & 3.0 \\
\hline & & Consequent & $\Delta v_{f}[\mathrm{~m} / \mathrm{s}]$ & 0.2 \\
\hline & \multirow{4}{*}{ Roll } & \multirow{2}{*}{ Antecedent } & $\theta_{f 4}[\mathrm{deg}]$ & 34.0 \\
\hline & & & $\omega_{f 4}[\mathrm{deg} / \mathrm{s}]$ & 3.0 \\
\hline & & \multirow{2}{*}{ Consequent } & $\Delta v_{f}[\mathrm{~m} / \mathrm{s}]$ & 0.2 \\
\hline & & & $\Delta \phi_{f}[\mathrm{deg}]$ & 62.0 \\
\hline & \multirow{3}{*}{ Yaw } & \multirow{2}{*}{ Antecedent } & $\theta_{l 1}[\mathrm{deg}]$ & 1.0 \\
\hline & & & $\omega_{l 1}[\mathrm{deg} / \mathrm{s}]$ & 4.0 \\
\hline & & Consequent & $\Delta \phi_{f}[\mathrm{deg}]$ & 62.0 \\
\hline \multirow{6}{*}{ Downhill } & \multirow{3}{*}{ Pitch } & \multirow{2}{*}{ Antecedent } & $\theta_{p}[\mathrm{deg}]$ & 2.4 \\
\hline & & & $\omega_{p}[\mathrm{deg} / \mathrm{s}]$ & 3.0 \\
\hline & & Consequent & $\Delta \phi_{f}[\mathrm{deg}]$ & 62.0 \\
\hline & \multirow{3}{*}{ Roll } & \multirow{2}{*}{ Antecedent } & $\Delta \theta_{4}[\mathrm{deg}]$ & 34.0 \\
\hline & & & $\Delta \omega_{4}[\mathrm{deg} / \mathrm{s}]$ & 3.0 \\
\hline & & Consequent & $\Delta \phi_{f}[\mathrm{deg}]$ & 62.0 \\
\hline
\end{tabular}

\section{$3 \cdot 3 \cdot 3$ 遺伝的操作}

GA における遺伝的操作としては，以下のものを用いた.

(a) 選択 : ルーレット選択を用いた. 寸なわち, 下記の確率 $p$ で, その個体が選択されるが，適合度 $f$ が高いも のほど，選択されやすくなる.

$$
p_{i}=\frac{f_{i}}{F}, \quad F=\sum_{i=1}^{N} f_{i}
$$

ここで, $N$ は個体数であり，添字 $i$ は $i$ 番目の個体を表す．また，個体群の中で最も適合度の高い個体を次世代に 残す, エリート保存則も用いた. これにより，優れた遺伝子型が遺伝的操作で破壊されるのを防ぐことができる.

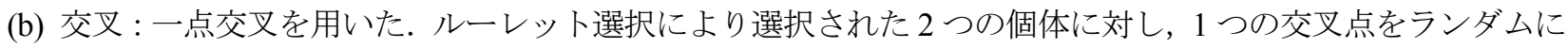
定め，その点を境に 2 つ個体の遺伝子を交換する.

(c) 突然変異 : ビット反転を用いた. 遺伝子の中からランダムに 1 bit $の$ 遺伝子座を選択し, その值を反転させ る. すなわち，選択したものが 0 ならば 1 に， 1 ならば 0 に変更する.

初期集団として， $N$ 個の個体を生成寸る．その際，各遺伝子はランダムに生成される．各個体に対して適合度 を算出し，選択，交叉，突然変異の操作を行い，次世代の個体群を生成する．この操作を，終了世代数になるま で繰り返し行う。

\section{$3 \cdot 3 \cdot 4$ メンバーシップ関数の設計結果}

GA の設定条件を以下に示寸.

- 個体数 $N: 30,-$ 終了世代数 : 500, - 交叉率 : $60 \%$, - 突然変異率 : $10 \%, \quad \cdot$ 試行回数 : 10 回

・制約条件 : リンク第 2 関節角度は $-40 \mathrm{deg}$ 以上 $40 \mathrm{deg}$ 以下, リンク第 3 関節角度は $-40 \mathrm{deg}$ 以上 $60 \mathrm{deg}$ 以下, リンク第 4 関節角度は $-30 \mathrm{deg}$ 以上 $75 \mathrm{deg}$ 以下, ロボットの加速度は $-0.6 \mathrm{~m} / \mathrm{s}^{2}$ 以上 $0.6 \mathrm{~m} / \mathrm{s}^{2}$ 以下 
適合度 $f$ 求める協調搬送制御シミュレーションの設定条件は以下の通りである.

・移動ロボットの初期配置 : 図 11 ・上り斜面路 : 図 12

・下り斜面路 : 図 13

・移動ロボットの加速度 : $0.4 \mathrm{~m} / \mathrm{s}^{2}$

・移動ロボットの速度 : $0.2 \mathrm{~m} / \mathrm{s}$

・シミュレーション終了時間 $t_{f}: 15 \mathrm{~s}$

(a) 上り斜面のピッチ角制御

図 12 の斜面を直進走行させるシミュレーションを行い, 適合度の值を算出した. このときの GA の探索過程を 図 14 に示寸. 同図は, 終了世代までの各世代で最も高い適合度をプロットしたものであり，探索が良好に行われ ていることがわかる.10回の試行を行い，その中で最も適合度が高いものを準最適解とし，そのメンバーシップ 関数の頂点值を用いた. 得られたメンバーシップ関数の頂点值を表 7 に示す.

(b) 上り斜面のロール角制御

水平路面上を直進走行させるシミュレーションを行い，適合度の值を算出した．ただし，搬送台のロール角に 変化が生じるように，フォロワ 2 に初期誤差として舵角 $1.0 \mathrm{deg}$ をえた. より問題を単純化するため, 斜面上で はなく水平路面上を走行させた. 表 8 に得られたメンバーシップ関数の頂点值を示す.

(c) 上り斜面（下り斜面）のヨー角制御

水平路面上を直進走行させるシミュレーションを行い，適合度の值を算出した．ただし，搬送台とリーダのヨ 一角が異なるように，リーダに初期誤差として舵角 $1.0 \mathrm{deg}$ を与えた．水平路面上を走行させた理由は，上記(b) と同じである. 表 9 に得られたメンバーシップ関数の頂点值を示す.

(d) 下り斜面のピッチ角制御

図 13 の斜面を直進走行させるシミュレーションを行い, 適合度の值を算出した. 得られたメンバーシップ関数 の頂点值を表 10 に示す.

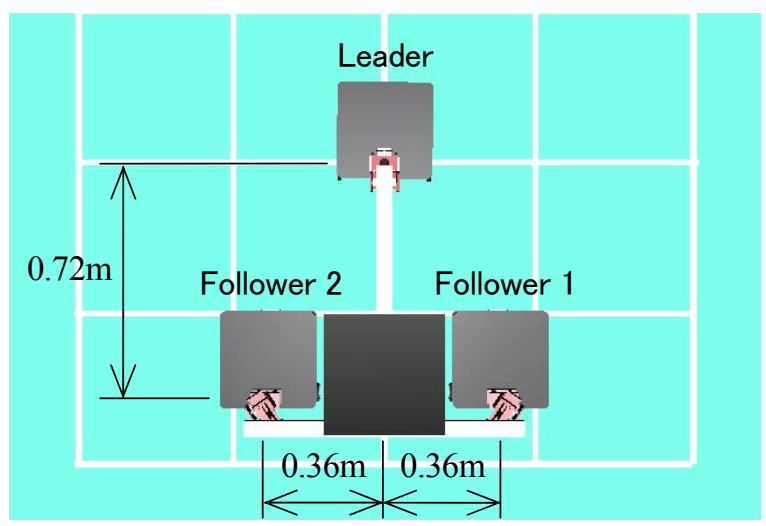

Fig. 11 Initial position of robots

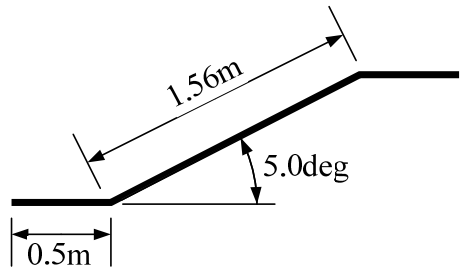

Fig. 12 Uphill transportation road

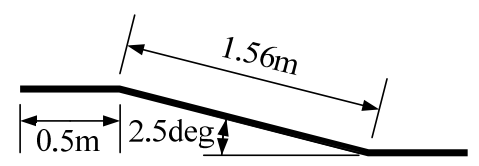

Fig. 13 Downhill transportation road

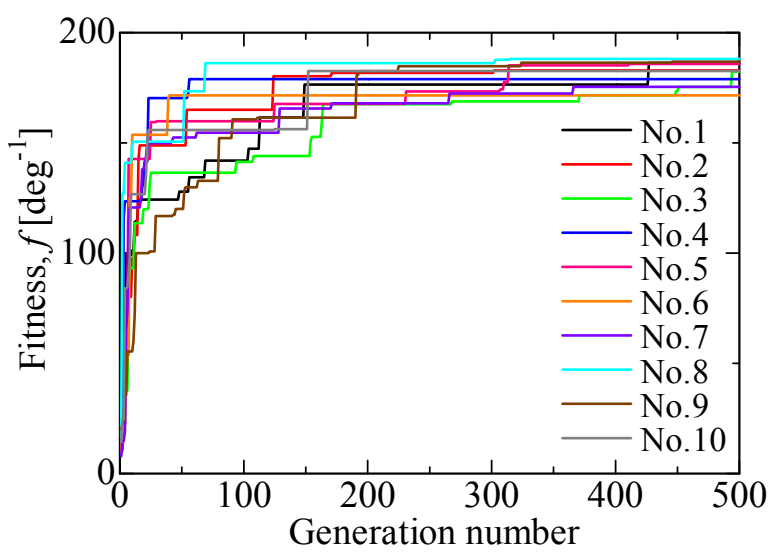

Fig. 14 Searching process of membership functions for pitch angle control on uphill by GA

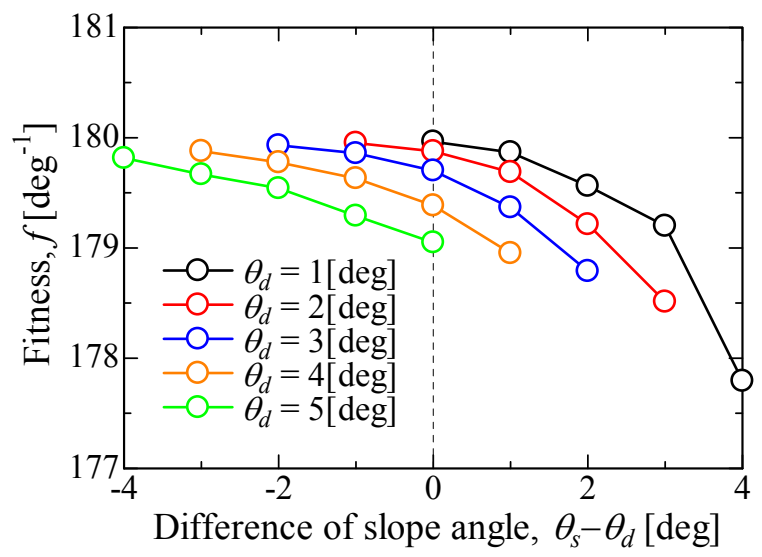

Fig. 15 Performance evaluation for difference between applied slope angle $\theta_{s}$ and slope angle $\theta_{d}$ used in design 
Table 7 Apex values of membership functions for pitch angle control on uphill

\begin{tabular}{|c|c|c|c|c|}
\hline \multicolumn{2}{|c|}{ Rule } & $a$ & $b$ & $c$ \\
\hline \multirow{2}{*}{ Antecedent } & $\theta_{p}[\mathrm{deg}]$ & $1.95 \times 10^{-2}$ & 1.35 & 2.40 \\
\cline { 2 - 5 } & $\omega_{p}[\mathrm{deg} / \mathrm{s}]$ & $3.87 \times 10^{-1}$ & 3.05 & 4.24 \\
\hline Consequent & $\Delta v_{f}[\mathrm{~m} / \mathrm{s}]$ & $1.96 \times 10^{-1}$ & $1.97 \times 10^{-1}$ & $2.00 \times 10^{-1}$ \\
\hline
\end{tabular}

Table 8 Apex values of membership functions for roll angle control on uphill

\begin{tabular}{|c|c|c|c|c|}
\hline \multirow{2}{*}{ Rule } & $a$ & $b$ & $c$ \\
\hline \multirow{3}{*}{ Antecedent } & $\theta_{f 4}[\mathrm{deg}]$ & $1.33 \times 10^{-1}$ & 4.65 & $1.95 \times 10^{1}$ \\
\cline { 2 - 5 } & $\omega_{f 4}[\mathrm{deg} / \mathrm{s}]$ & 1.70 & 1.89 & 3.38 \\
\hline \multirow{2}{*}{ Consequent } & $\Delta v_{f}[\mathrm{~m} / \mathrm{s}]$ & $7.81 \times 10^{-4}$ & $4.30 \times 10^{-2}$ & $5.00 \times 10^{-2}$ \\
\cline { 2 - 5 } & $\Delta \phi_{f}[\mathrm{deg}]$ & 7.02 & $6.03 \times 10^{1}$ & $6.08 \times 10^{1}$ \\
\hline
\end{tabular}

Table 9 Apex values of membership functions for yaw angle control on uphill and downhill

\begin{tabular}{|c|c|c|c|c|}
\hline \multicolumn{2}{|c|}{ Rule } & $a$ & $b$ & $c$ \\
\hline \multirow{3}{*}{ Antecedent } & $\theta_{l 1}[\mathrm{deg}]$ & $3.90 \times 10^{-3}$ & $4.65 \times 10^{-1}$ & $5.51 \times 10^{1}$ \\
\cline { 2 - 5 } & $\omega_{l 1}[\mathrm{deg} / \mathrm{s}]$ & $1.09 \times 10^{-1}$ & $9.53 \times 10^{-1}$ & 3.83 \\
\hline Consequent & $\Delta \phi_{f}[\mathrm{deg}]$ & $5.64 \times 10^{1}$ & $5.84 \times 10^{1}$ & $6.18 \times 10^{1}$ \\
\hline
\end{tabular}

Table 10 Apex values of membership functions for pitch angle control on downhill

\begin{tabular}{|c|c|c|c|c|}
\hline \multirow{2}{*}{ Rule } & $a$ & $b$ & $c$ \\
\hline \multirow{2}{*}{ Antecedent } & $\theta_{p}[\mathrm{deg}]$ & $2.93 \times 10^{-2}$ & $1.07 \times 10^{-1}$ & 1.71 \\
\cline { 2 - 5 } & $\omega_{p}[\mathrm{deg} / \mathrm{s}]$ & $3.52 \times 10^{-2}$ & $3.53 \times 10^{-2}$ & $1.29 \times 10^{-1}$ \\
\hline Consequent & $\Delta \phi_{f}[\mathrm{deg}]$ & $1.50 \times 10^{1}$ & $5.79 \times 10^{1}$ & $6.15 \times 10^{1}$ \\
\hline
\end{tabular}

Table 11 Apex values of membership functions for roll angle control on downhill

\begin{tabular}{|c|c|c|c|c|}
\hline \multicolumn{2}{|c|}{ Rule } & $a$ & $b$ & $c$ \\
\hline \multirow{2}{*}{ Antecedent } & $\Delta \theta_{4}[\mathrm{deg}]$ & $1.33 \times 10^{-1}$ & 4.65 & $1.95 \times 10^{1}$ \\
\cline { 2 - 5 } & $\Delta \omega_{4}[\mathrm{deg} / \mathrm{s}]$ & 1.70 & 1.89 & 3.38 \\
\hline Consequent & $\Delta \phi_{f}[\mathrm{deg}]$ & 7.02 & $6.03 \times 10^{1}$ & $6.08 \times 10^{1}$ \\
\hline
\end{tabular}

(e) 下り斜面のロール角制御

水平路面上を直進走行させるシミュレーションを行い，適合度の值を算出した. ただし，搬送台のロール角に 変化が生じるように，フォロワ 2 に初期誤差として舵角 $1.0 \mathrm{deg}$ を与えた. 水平路面上を走行させた理由は，上記 (b)と同じである. 表 11 に得られたメンバーシップ関数の頂点值を示す.

(f) 異なる斜度に対する制御性能評価

GA を用いてメンバーシップ関数の形状を設計したが，シミュレーションに用いた走行条件以外では，その最

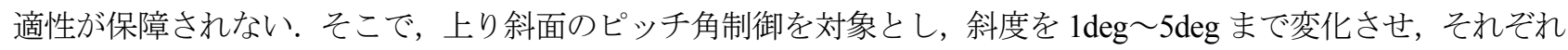
の斜度に対してメンバーシップ関数の形状設計を行った. 得られた各メンバーシップ関数を用い, 斜度 $1 \mathrm{deg}$ $5 \operatorname{deg}$ の斜面を走行させるシミュレーションを行った. その結果を図 15 に示す. 縦軸は適合度 $f$, 横軸は, 走行シ ミュレーションにおける斜度 $\theta_{s}$ とメンバーシップ関数の設計時に用いた斜度 $\theta_{d}$ との差， $\theta_{s}-\theta_{d}$ を表している. す なわち， $\theta_{s}-\theta_{d}=0$ は，設計時と同じ斜度の斜面を走行させたことを意味する．同図より，メンバーシップ関数の 設計時に用いた斜度よりも大きな斜度を走行させたときに $f$ 值が小さくなり，最適性（制御性能）が低下した ことがわかる。したがって，走行経路上に異なる斜度の路面が存在する場合には，最大斜度でメンバーシップ関 
数を設計すれば良い，同様に，搬送台のロール角制御やヨー角制御においても，想定される最大角度を与える条 件でメンバーシップ関数を設計すれば，より安全な設計をすることができる.

\section{4. 搬送台の水平化制御シミュレーション結果}

制御系の有効性を確認するため，図 16 に示す搬送路面上を直線走行させるシミュレーションを行った．図 11 に示す初期配置とし，移動ロボットは停止状態の Start 地点から，加速度 $0.4 \mathrm{~m} / \mathrm{s}^{2}$ で加速し，速度 $0.2 \mathrm{~m} / \mathrm{s}$ で等速走 行し, 加速度 $-0.4 / \mathrm{s}^{2}$ で減速して Goal 地点で停止する.

図 17 に搬送台のピッチ角の時間変化を示す. 比較のため, 水平化制御を行わずにフォロワがリーダと同じ走行 パターンで走行したときのもの，ならびに試行錯誤的に決定したメンバーシップ関数を用いたものも併せて示し た．なお，このシミュレーション条件では，搬送台のロール角ならびにヨー角は全く変化しない．水平化制御を 行わない場合には，斜面路と同じ斜度だけ搬送台のピッチ角が変化している．GA を用いてメンバーシップ関数 を決定したものでは，無制御の場合に対して，上り斜面で $8.0 \%$ ，下り斜面で $2.0 \%$ までピッチ角変化を低減する ことができている. また，試行錯誤的に決定したメンバーシップ関数を用いた場合に対して，上り斜面で $67 \%$, 下り斜面で $4.5 \%$ まで低減している.試行錯誤的に決定したピッチ角制御のメンバーシップ関数の頂点值を表 12 , 13 に示す.ロール角ならびにヨー角制御のためのメンバーシップ関数の頂点值も試行錯誤的に決定したが，これ らの制御則は使用されなかったため, ここでは省略する.

図 18 に, このときの移動ロボットの様子を示寸. 図中には, 水平化制御無しのものを薄く示してある. 同図(a) の上り斜面では，フォロワが減速することにより搬送台を水平に保持し，同図(c)と(d)の下り斜面では，フォロワ が両側に開くことにより搬送台を水平に保持している様子を確認することができる.

以上より，提案した制御系の有効性を確認することができた.

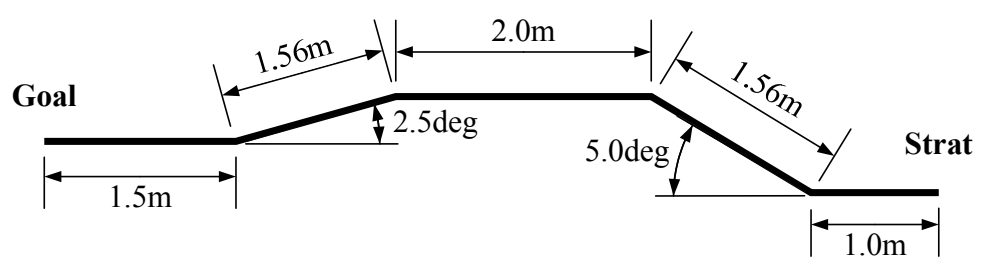

Fig. 16 Transportation road in simulation

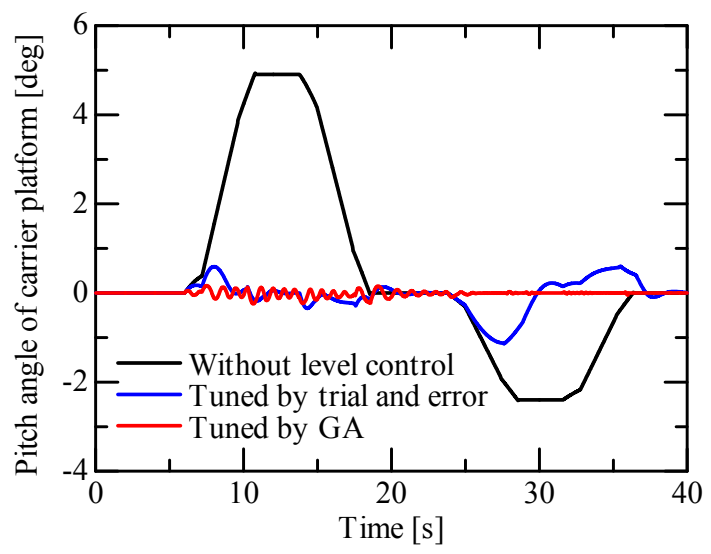

Fig. 17 Simulation result of level control 


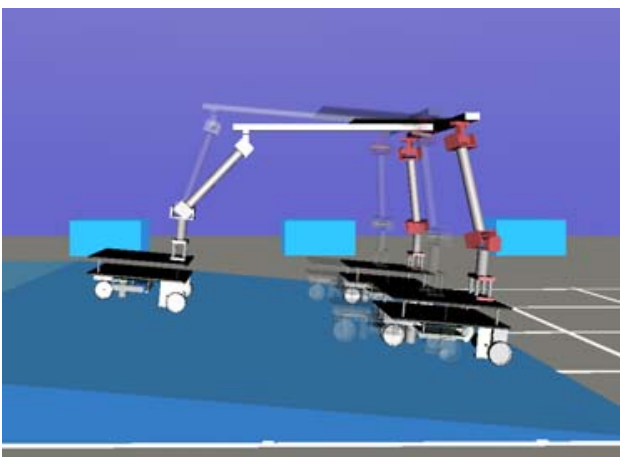

(a) Side view on uphill (Time $=13[\mathrm{~s}])$

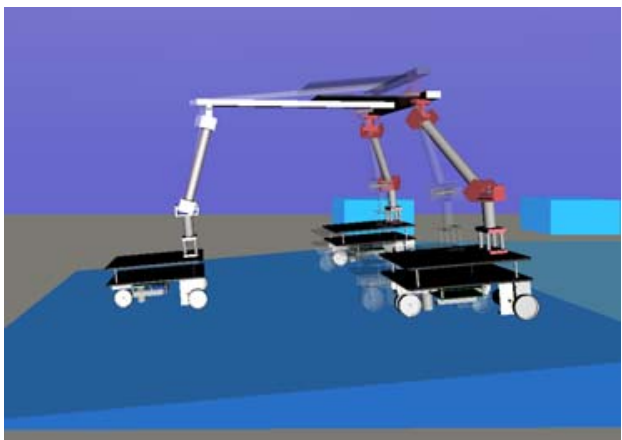

(c) Side view on downhill (Time $=30[\mathrm{~s}])$

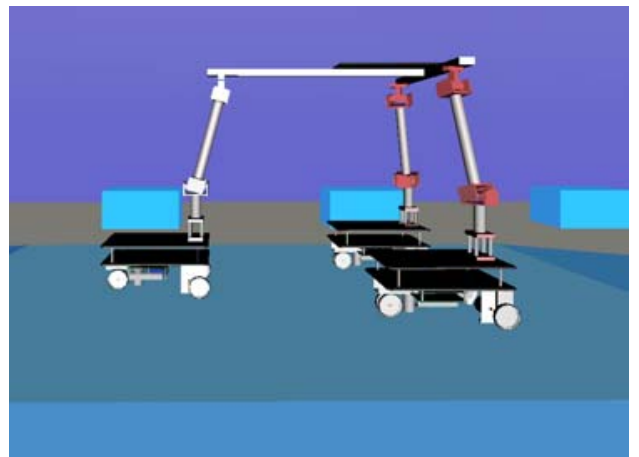

(b) Side view on plane $($ Time $=22[\mathrm{~s}])$

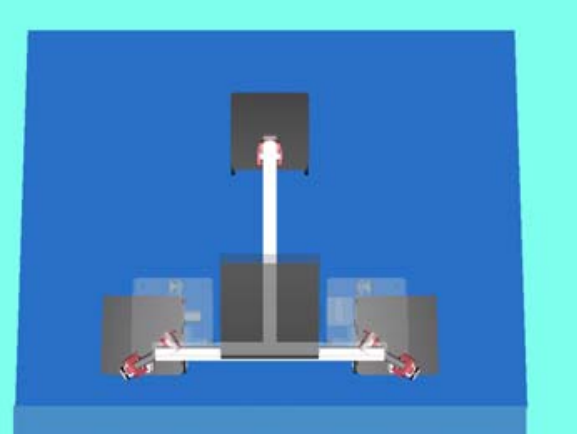

(d) Top view on downhill (Time $=30[\mathrm{~s}])$

Fig. 18 Scene of controlled robot in simulation

Table 12 Apex values of membership functions obtained by trial and error for pitch angle control on uphill

\begin{tabular}{|c|c|c|c|c|}
\hline \multicolumn{2}{|c|}{ Rule } & $a$ & $b$ & $c$ \\
\hline \multirow{2}{*}{ Antecedent } & $\theta_{p}[\mathrm{deg}]$ & $2.00 \times 10^{-1}$ & $4.00 \times 10^{-1}$ & 1.00 \\
\cline { 2 - 5 } & $\omega_{p}[\mathrm{deg} / \mathrm{s}]$ & $5.00 \times 10^{-1}$ & 1.00 & 2.00 \\
\hline Consequent & $\Delta v_{f}[\mathrm{~m} / \mathrm{s}]$ & $5.00 \times 10^{-2}$ & $1.00 \times 10^{-1}$ & $1.20 \times 10^{-1}$ \\
\hline
\end{tabular}

Table 13 Apex values of membership functions obtained by trial and error for pitch angle control on downhill

\begin{tabular}{|c|c|c|c|c|}
\hline \multirow{2}{*}{ Rule } & $a$ & $b$ & $c$ \\
\hline \multirow{2}{*}{ Antecedent } & $\theta_{p}[\mathrm{deg}]$ & $2.00 \times 10^{-1}$ & 1.00 & 1.50 \\
\cline { 2 - 5 } & $\omega_{p}[\mathrm{deg} / \mathrm{s}]$ & $1.00 \times 10^{-1}$ & 1.00 & 2.00 \\
\hline Consequent & $\Delta \phi_{f}[\mathrm{deg}]$ & 5.00 & $2.00 \times 10^{1}$ & $4.00 \times 10^{1}$ \\
\hline
\end{tabular}

\section{5. 搬送台の水平化制御実験結果}

制御シミュレーションにより，本制御系の有効性を確認することができたので，つぎに，制御実験を行った. 図 19 に示寸搬送路面上を直進走行させる実験を行った。 なお，実験室の広さの都合上，上り斜面と下り斜面に分 けて制御実験を行った.移動ロボットの初期配置ならびに走行条件は制御シミュレーションのものと同一とした.

上り斜面路における搬送台の水平化制御実駼結果を図 20 に示す. 比較のため, 水平化制御を行わずに走行させ たときの結果も示した．水平化制御を行わない場合，制御シミュレーションでは，搬送台のロール角ならびにヨ 一角は変化しなかったが，実験結果ではこれらの角度が変化している．これは，走行時に発生する車輪のスリッ プや移動ロボットのデッドレコニング誤差により, 各移動ロボットの相対位置が変化したためだと考えられる. 水平化制御を行わない場合は，上り斜面に進入後，搬送台のピッチ角が大きく変化し，斜面路を退出後には，搬 送台のロール角が大きく変化している. また，リーダリンクの第 1 関節の角度は零になっておらず，リーダと搬 送台のヨー角が一致していない，搬送終了後，全ての姿勢角が零にならず，搬送台が傾いた状態になっている. 
水平化制御を行った場合は，搬送台のピッチ角ならびにロール角が零に保たれており，搬送台を常に水平保持 している. リーダリンクの第 1 関節の角度も零に保たれており，リーダと搬送台のヨー角が同じ，すなわち，リ 一ダとフォロワが同じ方向に走行している.このときのロボットの様子を図 21 に示す. 後ろの暗幕に白い紐を水 平に張ってある.この紐を目安にすると搬送台の水平状態が良くわかる. 同図(b)の斜面上ならびに同図(c)の搬送 終了時に，搬送台が水平に保持されていることを確認することができる．同図(c)のロボットの相対位置が，同図 (a)の初期位置とほとんど変化していないことより，搬送台のロール角ならびにヨー角も変化していないこともわ かる.

下り斜面路における搬送台の水平化制御実験結果を図 22 に示す. 比較のため, 水平化制御を行わずに走行させ たときの結果も示してある. 水平化制御を行わない場合は, 搬送台のピッチ角が下り斜面進入後に大きく変化し ている. フォロワ 2 が下り斜面から水平面上一進入する際（約 15 秒頃）に左方向を向いてしまった．これは，斜 面路と水平路面の繋ぎ箇所の段差に起因するものと考えられる. これにより，搬送台のロール角が負方向へ大き く変化し，リーダリンクの第 1 関節の角度が正方向へ大きく変化してしまった. さらに，搬送台のピッチ角も， この影響で約 20 秒辺りから負方向へ大きく変化した.

水平化制御を行った場合には，搬送台のピッチ角，ロール角，ならびにリーダリンクの第 1 関節の角度が零に 保たれている. 上り斜面の結果と比較すると，それぞれの角度の変化量が大きくなっている. 搬送台の水平化制 御において，上り斜面では主にフォロワの速度を制御し，下り斜面ではフォロワの速度と舵角の両方を制御しな ければならない，そのため，下り斜面の方がより水平化制御が困難になる．また，フォロワの舵角が制御される ことにより, 搬送台のロール角ならびにヨー角も変化しやすくなる. これらが，下り斜面路での制御性能を低下 させた原因であると考えられる。

以上より，上り斜面では，搬送台のピッチ角，ロール角，ならびにリーダリンクの第 1 関節の角度を $\pm 2 \operatorname{deg}$ 以 内に，下り斜面では，それらをさ4deg 以内に収めることができ，提案手法の有効性を確認することができた.

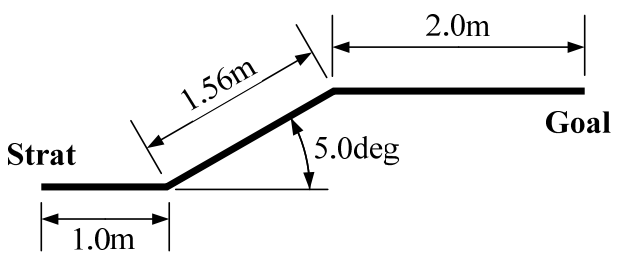

(a) Uphill

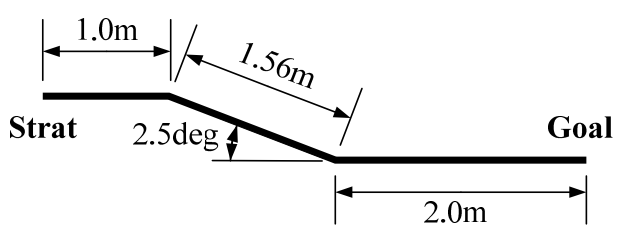

(b) Downhill

Fig. 19 Transportation road in experiment
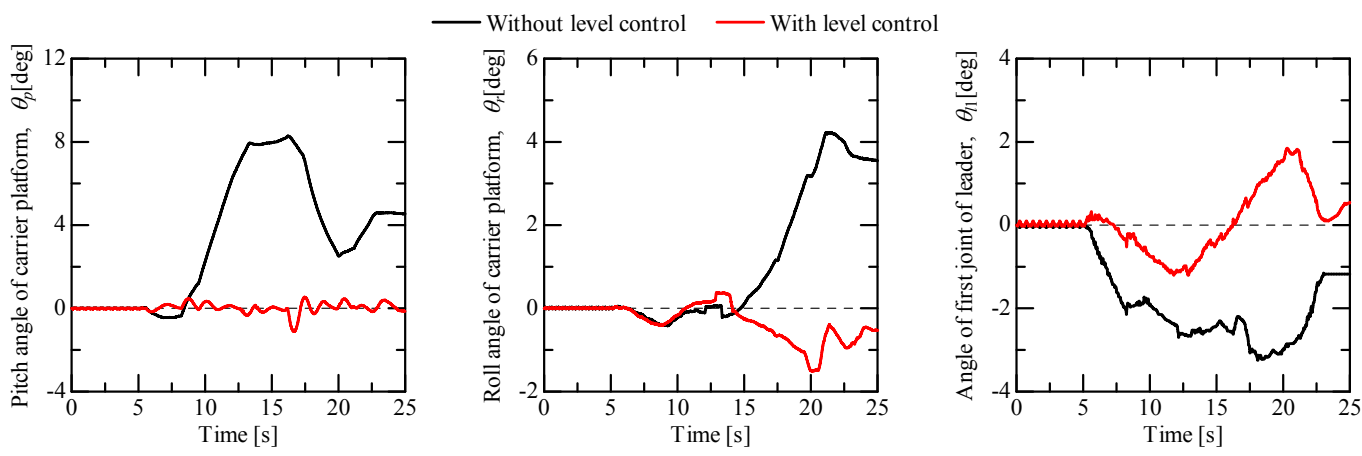

Fig. 20 Experimental results of level control on uphill transportation road 


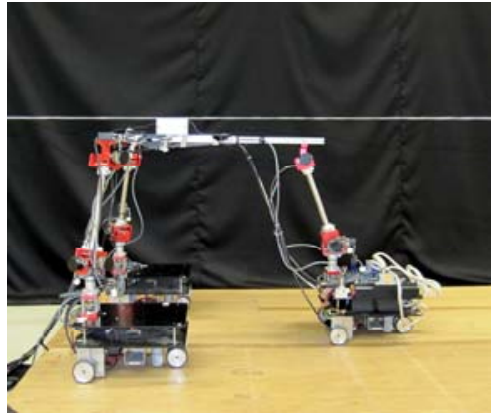

(a) Start

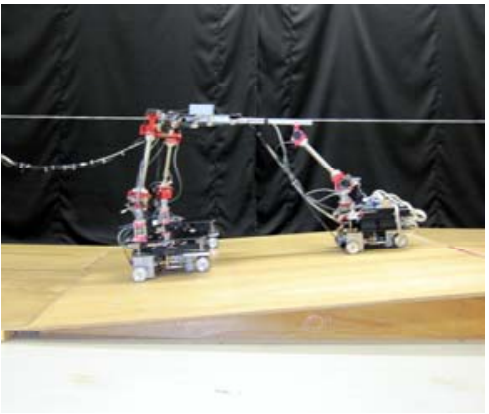

(b) Uphill

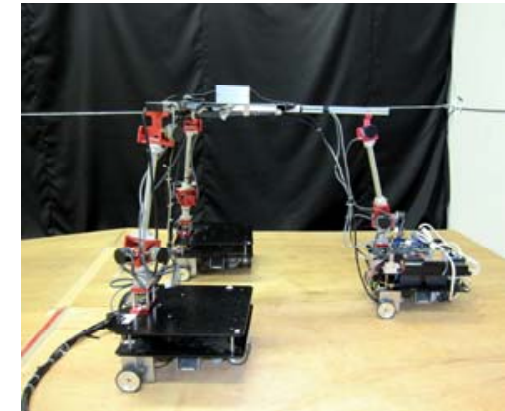

(c) Goal

Fig. 21 Scene of controlled robot in level control on uphill transportation road
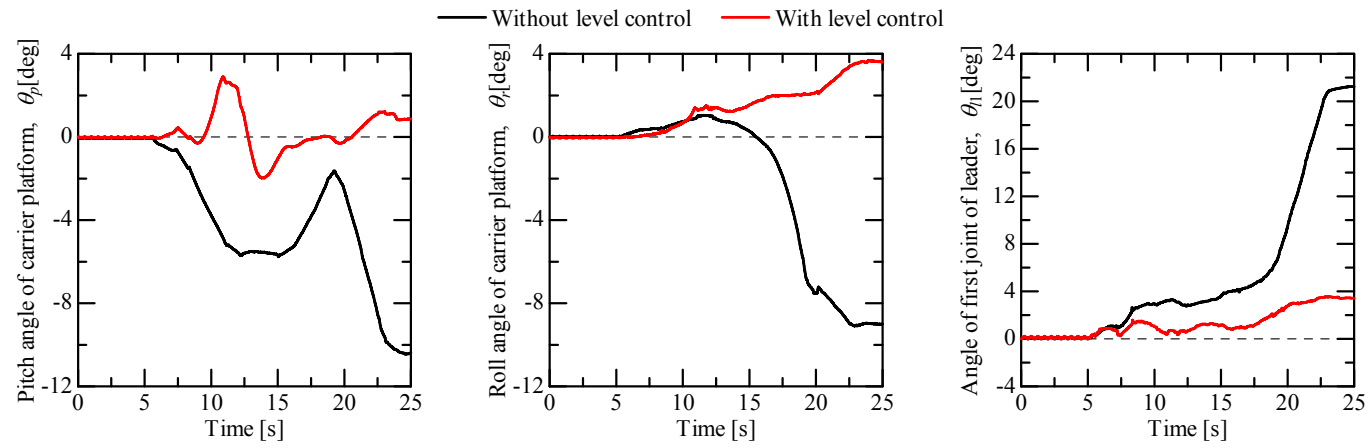

Fig. 22 Experimental results of level control on downhill transportation road

\section{6. 結言}

受動関節機構を有するパラレルリンク機構を搭載した移動ロボットの協調搬送システムを対象とし，斜面路を 含む経路において搬送台の水平化制御を行った．得られた結果を以下にまとめる.

1) 上りならびに下り斜面路を走行する際に，搬送台を水平に保つためのファジィルールを作成した.

2) ファジィ理論のメンバーシップ関数を, 遺伝的アルゴリズムを用いて合理的に設計した.

3) 提案手法の有効性を, 制御シミュレーションならびに制御実験により確認した.

提案手法と文献(12)の制御実験結果を比べると, 提案手法の制御性能の方が若干低くなっている. 提案手法で は，簡略化のために，メンバーシップ関数の形状を直線で表し，零を中心とした左右対称のものとした（図 5 参 照).この形状をシグモイド関数などの曲線とし, 左右非対称なものにすることにより, 制御性能を向上させるこ とができると考える.ただし，提案手法は，「移動口ボットは，同一平面上にあるものとする」という条件が付加 されないため, 文献(12)のものより適用範囲の広い方法であると言える. 移動ロボットの数が増加して機構が複 雑になれば，幾何学モデルの導出は困難になる。しかし，本手法は，幾何学モデルを利用しないため，機構が複 雑化したシステムへの適用が容易であるという利点も有する.

提案手法では，搬送台のピッチ角，ロール角，ならびにヨー角制御のためのファジィルールを個別に作成し， これらから出力された操作量を重ね合わせて最終的な操作量とした. そのため，あるルールが他のルールに悪影 響を与えている可能性がある. そこで, 個別にファジィルールを作成するのではなく, 統一的に取り扱うことに より，制御性能がさらに向上すると思われる.たとえば，搬送台のピッチ角，ロール角，ヨー角ならびにそれら の微分值を入力とし, フォロワの速度と舵角を出力とする 6 入力 2 出力のファジィルールを作成する.この場合, ルールのラベル（NB，NM, NS など）をどのように貼り付ければ良いのかを設計者が考えるのは非常に困難に なる. そのため, メンバーシップ関数の形状設計のみならず, このラベル付けにも遺伝的アルゴリズム等の最適 化手法を利用する必要がある. 


\section{文献}

(1) 吉村裕司, 太田順, 井上康介, 平野智一, 倉林大輔, 新井民夫, “群ロボットによる多数物体の繰り返し搬送計画”, 日本ロボット学会誌, Vol. 16, No. 4 (1998), pp. 75-83.

（2）浅間一, 尾崎功一, 松元明弘, 石田慶樹, 遠藤勲, “通信を用いた分散的管理に基づく移動ロボットの協調的作業 分担決定手法”, 日本ロボット学会誌，Vol. 10, No. 7 (1992), pp. 111-119.

(3) 梶谷誠, “2 台の移動ロボットによる運搬作業”, 日本ロボット学誌，Vol. 12, No. 6 (1994), pp. 41-41.

(4) 加藤晋, 武野純一, “複数の移動ロボットの協調”, 日本ロボット学会誌, Vol. 12, No. 6 (1994), pp. 785-790.

（5）橋本雅文, 大場史憲, 江口透, “複数の移動ロボットによる動的搬送制御”, 日本ロボット学会誌, Vol. 13, No. 6 (1996), pp. 856-893.

(6) 小菅一弘, 大住智宏, 千葉晋彦, “単一物体を操る複数移動ロボットの分散協調制御”, 日本ロボット学会誌, Vol. 16, No. 1 (1998), pp. 87-95.

(7) 太田順, 武衛康彦, 新井民夫，大隅久，陶山毅一，“2 台の移動ロボットによる協調搬送制御”，日本ロボット学会 誌, Vol. 14, No. 2 (1996), pp. 263-270.

（8）山下淳, 福地正樹, 太田順, 新井民夫, 淺間一, “移動ロボット群による大型物体搬送計画”, 日本機械学会論文集 C 編，Vol. 68, No. 665 (2002), pp.165-172.

（9）大隅久，“位置制御系を有する複数のロボットによる協調搬送システムの設計”，日本機械学会論文集 C 編，Vol. 65 , No. 634 (1996), pp. 245-252.

(10) Osumi, H., Terasawa, M., and Nojiri, H., "Cooperative Control of Multiple Mobile Manipulators on Uneven Ground", Proceedings of the 1998 IEEE International Conference on Robotics and Automation, Vol. 4 (1998), pp. 3198-3203.

(11) 大隅久, 野尻尚, 栗林廉, 岡崎崇, “3 台の自律移動ロボットによる物体の協調搬送制御”, 日本ロボット学会誌, Vol. 19, No. 6 (2001), pp. 744-752.

(12) 浜口雅史, 谷口隆雄, “受動関節機構を有する移動ロボットによる協調搬送制御（斜面路走行における幾何学モデ ルを利用した搬送台の水平化制御)”，日本機械学会論文集 C 編，Vol. 78, No. 792 (2012), pp. 2898-2913.

(13) 小山宏, 前田陽一郎, 深海悟, 高木友博, “ファジィプロダクションシステムによる移動ロボットの障害物回避問 題の検討”， 日本ロボット学会誌，Vol. 9, No. 1 (1991), pp. 75-78.

（14）永田英夫，土谷武士，“移動ロボットの障害物回避に関する知的制御”，日本ロボット学会誌，Vol. 11, No. 8 (1993), pp. 1203-1211.

(15) 石川繁樹, “ファジィ制御を用いた自律型移動ロボットの誘導方式の検討”, 日本ロボット学会誌, Vol. 9, No. 2 (1991), pp. 149-161.

(16) Aguirre, E. and González, A., "Fuzzy behaviors for mobile robot navigation: design, coordination and fusion", International Journal of Approximate Reasoning, Vol. 25 (2000), pp. 255-289.

(17) 福田敏男, 長谷川泰久, 下島康嗣, “遺伝的アルゴリズムを用いた階層型ファジィモデルの自動生成法”, 日本ファ ジィ学会誌, Vol. 7, No. 5 (1995), pp. 988-996.

(18) Carse, B., Fogarty, T. C., and Munro, A., "Evolving fuzzy rule based controllers using genetic algorithms", Fuzzy Sets and Systems, Vol. 80 (1996), pp. 273-293.

(19) Arslan, A., and Kaya, M., "Determination of fuzzy logic membership functions using genetic algorithms", Fuzzy Sets and Systems, Vol. 118 (2001), pp. 297-306.

（20）三矢直城，田中一男，C 言語による実用ファジィブック，(1989), pp. 8-70，ラッセル社.

（21）田中一男，アドバンストファジィ制御，(1994), pp. 1-66, 共立出版.

(22) 坂和正敏, 田中雅博, 遺伝的アルゴリズム，(1995), pp. 1-203, 朝倉書店.

(23) 三宮信夫, 喜多一, 玉置久, 岩本貴司, 遺伝的アルゴリズムと最適化, (1998), pp. 1-185, 朝倉書店. 